I offer Raspail's objections to Liebig's metbod of analysing organic substances, which I conceive to be quite sufficient to demonstrate inevitable fallacies in all the results. Could vot a committee of medical chemists determine a course of experiments on this mysteriously interesting subject, and, abaorloning all prejudices, fully and tairly unravel its nature? The sanction of Euch a powerful authority would be inf. nitely more satisfactory to your renders and to the public, than the solitary investiga. tions of a rustic amateur. Yours very truly,

Wraxall, near Bristol,

Chas. T. Coathupe. A pril 1, 1839.

\section{ORIGIN OF HIDROPHOBIA.}

\section{To the Editor of Tur Laxcet.}

Sir :- L iave just purchased Dr. Klein Grant's new and improved edition of Hooper's " Medical Dictionary," and having naturally turued to the article " Hydrophobia," I,: with some, little surprise, read as follows:- "Uf the cause of this peculiur distemper in dogs, nothing certain is known; that it originates spontaneously in them is now the generul opinion."

Perinit me to ask this gentleman on what ground he rests this assertion? Does he refer to veterinary practitioners, who may be supposed to have the fairest chance of arriving at the truth respecting their own patients! Nineteen ont of twenty will tell him, that " the cause of this peculiar distemper in dogs is known; that it never originates spontancously in the dog; but is propogated from one tu another by the bite." I am aware that there are a few who maintain a contrary opinion, but $I$ am speaking of the overwhelming majority of practitioners.

Does he refer to the practitioners of human medicive! I must, in this case, remind hin that in the year 1831, a Committee of the House of Commons inquired into the subject of rabies. To sir of the medical gentlemen who were examined, this very question was put:- " Do you believe that rabies originates spontaveously in the dog ?" "No," was the unlesitating reply of thrce of them,-Drs. Babington and A.T. Thom. son, and Mr. Earle. Mr. Morgan stated that it was the preponderance of his opinion that rabies was a disease to be communicated solely by the bite of another animal previously rabid." Sir Benjamin Brodie said, that " he bad not been able to make up his miud, whether the disease does or does not, ever arise spontaneously." Mr. Frankun alone professed his belief in its spontaneous origin.

It seems that it was not then, "the geweral opiaion" that rabies "origiantes spon- taneously " in the dog. $\mathbf{F}$ hat has caused the sudden chango of opinion in medical men ; or bas any change really taken place? Where, and by whom, has it been ex. pressed ?

Against some previous septences in Dr. Grant's account of bydrophobia I muat respectfully enter my protest. This dis. ease has been communicated by herbirorous and omnivorous animals; and, if the account of Magendie and Breschet is to be depended upon, by the human being. This subject is somewhat fully discussed in the "Veterinarian" for June 1838. I must confess it to be my frm opinion, that every animal, capable of being infected by the rabid irus, can propagate the disease. Yours obediently,

$$
\begin{gathered}
\text { Adan's-terrace, Camdea-town, } \\
\text { April 1, } 1839 .
\end{gathered}
$$$$
\text { IV. Yount, V.S. }
$$

\section{PRESERVATION OF DEAD BODIES.}

\section{To the Fditor of The LAyceT.}

SIn:-A year or two ago various notices appeared in several of our British Jourauls, both literary and medical, of the process discovered by Signor Girulamo Legato, a Florentine gentleman, for preserving, in an extraordinary degree of perfection, the human hody, and all objects of natural his. tory. By some the whole discovery was treated as a fable; by uthers, who had seen the preparations, accounts so extraordinary were promulgated, that the ever-cautious scientific bodies of this county received them with distrust. This incredulity was greatly strengthened by a pamphlet, written about 1835, by the Adrocate Pellegrini, a friend of Legato's, and of which several copies found their way into Britain. Nothing could have been more calculated to injure the discoverer than this publication, couched in the most high-flown langunge, and contaiuing statements uften directly at variance with the laws of science. I have not, at present, the opportunity of consultung the rarious accounts above nilluded to, nor is it necessary to do 80 , as 1 here wish to relate only the results of my own observa. tion of the, specimens, $\mathbf{n}$ ithout trusting to the accounts of others. On visitiug Florence. in May, 1838, I inmediately inquired for the cubinet of Legatu, he himself haring died nearly two years before. It was with cunviderable difficulty that 1 obtained pernission, through the hindness of Professor Betti, to inspect the preparations, as they are not now shuwn to every visitor. Signor Fumigalli, in whose honse they are at preseot preserved, allowed me to bandle and examine each specimen at my leisure, and most courteously assisted we with all the information in his power. The following is 
an extract from the observations $I$ then committed to paper, May 5 th, 1838 :-

"It is stated in the pamphlet of the Advocate Pellegrini, which I read two years ago in Edinburgh, that the objects prepared by Legato possessed the hardness of stone, with the flexibility of the liring fibre. They do not; but their general hardness is akin to that of mahogany (I mean of the preparations of internal organs), while the integuments of the hands, feet, \&c., feel as if a tight cover of parchment, or white leather, had been drawn over the horny, yet still pretty flexible, muscles and tendons. Most of the preparations can be indented by the nail, but require considerable force to be exerted before you can leave any mark upon them, though any iron instrument would scratch them as easily as it would rosewood or mahogany.

The foot of a young woman was the first object shown to me; it was of a deadwhitish colour, like that of a corpse, and the skin felt as if half tanoed, and adhered very closely to the subcutaneous tissues. There was not here the plumpuess of life; but it was not much more shrunk than is the foot of a person who has died of a lingering disease. The muscular parts of the plantar surface of the foot appeared shrunk in proportion to the rest of the tissues, though as very little fat appeared at the point of amputation, I suspect the subject had been an emaciated one. The foot had been severed about an inch above the ankle-joint, where little muscular substance is found; but what I saw was of a light yellowish-brown colour, and had the feel and consistence of horn. The toes of this foot were flexible to a very considerable degree. Of two hands the colour of the skin was considerably darker, approaching to a li rsht-brown; but all the fingers were flexible, though some. what stiff. About the foot I thought I could still perceive a very faint smell of fat; but the hands were perfectly inodorous. In the same drawer was the head of a foetus of about eight months, which was, indeed, curious, as the prucess of putrefaction, which had commenced, had been completely and suddenly arrested. Here the colours were well preserved, the greenish hue of incinient decay, being very apparent, the skin nearly of the natural colour, and the whole hard and firn, nor much less plump than in life. I found it very difficult to imprint any mark with my nail upon this head; the soft down on the scalp was perfect. In the same drawer was a portion of liver, bardened and polished on one side; this did not please me. its colour was so dark that but for the form I could not have recognised it, nor could I perceive any traces of acini, or veins. It could be indented by the nail, and was much lighter than a similar portion of fresh liver, being little heavier than a portion dried by exposure to the air, although it differed from this, in being little, or not at all, diminished in size. In a flat piece of woud were several inlaid and polished portious of various organs und tissues of the human body. I may particularly instance two large round portions of the placenta, wherein the red blood-vessels, running in every direution in the yellowish surrounding tissue, resembled, very closely, some of the varieties of serpentine. In another square of wood, were inlaid two portions of the kidney, cut and polished, and beside them two pieces of polished box-wood. The latter I could easily indent with my nail; the former received no impression whatsoever from all the force $I$ could exert. Perhaps the greatest curiosity was a little tablet, about a foot and a half square; portions of the human body, to the extent of about 80 different pieces, are here inlaid in small cubes. Nothing can be more beantiful than the polished slices of hardened cuti. cle from the soles of the feet; they are ex. tremely hard, yellowish, and transparent, like the yellow sulphate of lime from Volterra. Portions of the kidneys, tonsils, lungs, \&c., exhibited their natural hue, and could be instantly recognised by any one at all conversant with their structure. In a grlass case is the thorax of a young girl of 17 ; the plumpness of the mammx is here admirably preserved; but though I do not suspect Legato of any deceit, I should have wished to have examined it more closely, ere I would assert that the parietes of the thorax were perfectly entire. The appearance of the skin, in this case, raised a suspicion in my mind, for it exactly resell. bled white leather, having all the glistening appearance of tanned sheepskin. I speak cautiously of this specimen as I could not handle it, and the edges were entirely concealed by drapery.

: By far the most satisfactory part of Legato's preparations are the perserved fislies, reptiles, and insects; these far exceeded my most sanguine expectations. Some lizards and small serpents are hard as horn, very light, and every scale, every proportion, and their colour, are perfectly preserved, A few birds, among the rest a canary bird and a chaftinch, have been subjected to this process. Though less resembling life than the hirds stuffed by Waterton, or our best London preservers, their bodies are pretty plump, and perfectly hard and compact; but the moths, which abound in the case where they lie, bave made sad havoc with their feathes. The canary bird, as we are told by Pellegrini, and as $I$ was also assured by Signor Fumigalli, was placed under water for two months during the life time of Legato, and, at the end of that period, taken out unchanged. The destroyintr moth could not evidently advance farther than the feathers; nor could they injure any insects that had been sub- 
-jected to the preservative process; for while numerous other unprepared ones in the same case had been nearly, or totally ruined, those prepared, though some were of the tenderest description, had escaped uninjared. Ilere were also numerous dissections of frogs, toads, and fish. A perpendicular section of a perch was very remarkable, as the' colours and proportions of the parts had been most completely preserved. It appeared to me that this specimen had been enrnished, but certainly it had not been painted. A portion of the brain of a child was extremely hard, but of a light hair-brown colour, somew hat greasy to the touch, and by Do means free from animal odour. Signor Fumigalli showed me one of the fish which, he said, was " not completely sulicified through," and stated that several of Legato's earlier preparations had had the same defect. The parts farthest remote from the circurn. ference were certainly, in this instance, much softer than the internal ones, though, at the same time, they did not appear shrunk."

Such are the results of $\mathrm{my}$ examination of these specimens, and I have cupied them exactly from the notes taken on the day of the visit. I hope that I have shown that the accounts of some previous writers, though exaggerated, were by no means altogether univorthy of credit. From a personal friend of Legato I received a few particulars concerning him, which may not be without in. terest to some of the readers of THE LANCET.

Legato was, unfortunately, obnoxious to the Government of Tuscany, on account of his extreme liberal opinions. He, on one occasion, presented a petition to the Grand Wuke to be allowed to preserve the entire body of a child of 11 or 12 years of age, and prayed, that should any such die in the hospital unclaimed, it might be given over to him. The petition was referred by the Grand Duke, who really admired, but dared not openly favour bin, to a committee, and here the malice of his enemies prevailed, and the humble request was denied. Too poor to purchase, even in Florence, where a body costs but a few francs, Legato was obliged to content hinself with what his friends could supply, and was never able to make trial of his process on a grand scale. But this would have been of but small moment ; time would have done justice to his merits, had not, through his childish eelishness or timidity, his secret gune with him to the grave. So fearful was he lest it might be discovered, that he never would commit the slightest hint of it to paper, though repeatedly entreated to do so by his friends. They earnestly begged him, at least, to leave it in his will, which would remain sealed till after his death; but, with a childish obstinacy, he constantly refused. On his death-bed, Mr. Sloane, my informant, and othen of his frieads, renewed their solicitations, and at length, comvineed that be could not snrvire, he appointed the next morning to reveal to them his process. The morning came; they repaired to bis bonse; Legato was speechless, and died is the course of the day. His collections have been carefully preserved; and, as $n$ com. mission bas been named by the Goveroment to treat for the purchase of them, it is to he hoped that, ere long, they will be freely opened to scientific investigation and analy. sis, by which alone we can now hope to obtain a hint of the mode of preserving objects so perishable. But, should this method be entirels lost, I trust that this account of the specimens preserved by it, will prove that it is a misfortune to be deeply regretted by the scientific world. Yours, \&c.

Eimard Charlton, M.D.

1i, Gluucester-street, Queen-square, Marcb 26, 1829.

\section{MALARIA IN IRELAND.}

\section{To the Fditor of TuE Laxcet.}

SIR :-I was not a little surprised that the interesting subject of malaria, so long and so ably discussed at the Westminster Medical Society, should come to a conclusion without once referring to Ireland and its extensive bogs. If decomposed regetable matter, as it is usually supposed, be the cause of malaria, surely it is there we must look for it in the greatest abunilance. But what is the fact? Why, that iutermittent fevers are almost, if not wholly, unknown there. I allude most particularly to the bug of Allen. It must be admitted that the Irish peasantry are constantly exposed to miasma (if such existed), for they are obliged, for the sake of fuel, to live us near as possible to these bogs; and, indeed, in many instances, huts are built in the midst of them. Notwithstanding all such predisposing causes, ague is rarely, if ever, known there. One strong proof of its non-existence is, that it is almost a proverb with the poor people who come over to England during harvest time, that they are sure to get the ague before they return. Still, typhus ferer, in its sererest form, is not an uncominon occur. rence. So much for Ireland. Now for We les; or, rather, the small town of Towyu, in Merionethshire, containing about 500 inhabitants, where 1 believe I shall not be far wrong if 1 say a third of the inhabitants are annually attacked with aque. To all external appearances the ground upon $w$ hich this town is built and the burders of the bog of Allen'are alike ; certainly, the turfs dug from each, as far as I ani capable of judging, are identical. The fifieen years that 1 lived in Toryu I suffered from six allacks of ague, and those within the last ten yenrs; since I left 1 nerer bad the slightest syp- 